\title{
Transformace, restrukturalizace, revitalizace
}

\author{
Miloslav Synek ${ }^{I}$
}

\section{Transformace ekonomiky - přechod k tržnímu hospodářství}

Vstup ČR do EU předpokládal, že české hospodářství bude plně transformováno, tj. že dříve centrálně řízená ekonomika (command economy) bude přeměněna na ekonomiku tržní. Procesem transformace musela projít nejen ekonomika ČR, ale prakticky ekonomiky všech bývalých socialistických zemí střední a východní Evropy (země SVE). Samozřejmým předpokladem ekonomické transformace je změna politického systému, která spočívá ve vytváření kapitalistického společenského systému, což je proces daleko širší než změny v ekonomice; tato změna však není předmětem naší publikace 2 .

Za obecný cíl transformace ekonomiky se obvykle považuje vybudování (zavedení) tržního hospodářství (market economy) ${ }^{3}$. Je spravedlivé uvést, že určité prvky tržního hospodářství existovaly i v centrálně řízené ekonomice (stejně jako v tržních ekonomikách existují zásahy státu do ekonomiky), že však tato ekonomika byla v podstatě centrálně řízena (plánována) a hlavní charakteristiky tržní ekonomiky jí chyběly. Při hodnocení úspěšnosti transformace $v$ jednotlivých zemích je nutné přihlédnout i k výchozím podmínkám; $\mathrm{k}$ těm patří např. rozměr ekonomiky (rozlišující se velké země nad 50 mil. obyvatel, země středního rozměru 15 - 50 mil., malé země 5 - 15 a velmi malé země do 5 mil., ČR tedy patřila k malým zemím), výkonnost ekonomik (měřená nap̌r. HDP/obyvatel, ČR patřila k předním zemím SVE), svázanost s RVHP (v ČR byla jednou z nejvy̌ších), podíl soukromého sektoru a existence prvků tržního hospodářství v rámci centrálního řízení (v ČR mizivé). Za cíl transformace v ČR bylo možné považovat „vybudování normálně fungujícího tržního hospodářství, které spočívá na soukromém vlastnictví a soukromé iniciativě a které funguje na stejných principech jako západoevropské a severoamerické hospodářstvi““4 Uved’mgještě, že Evropská banka pro rekonstrukci a rozvoj (EBRD) v pravidelně publikovaných zprávách charakterizuje postavení jednotlivých transformujících se zemí ve čtyřech

1 Prof. Ing. Miloslav Synek, CSc., Katedra podnikové ekonomiky Fakulty podnikohospodářské Vysoké školy ekonomické v Praze.

2 Zcela odlišný př́ístup přechodu k tržní ekonomice zvolila Čína. Uved'mede některé závěry, ke kterým dospívá Jan Adam z University v Calgery (Co nás může naučit čínská strategie přechodu k tržní ekonomice. Politická ekonomie č. 1/1997):

- vláda hraje důležitou roli v řízení ekonomiky, hlavně při její restrukturalizaci,

- politický systém v Číně je autoritářský a nemůže si dovolit pokles výroby a životní úrovně,

- privatizace není podmínkou dobrého výkonu, nemluvě o restrukturalizaci ekonomiky,

- ekonomika může dosahovat vysokého růstu, i když nejsou vlastnická práva dobře definována,

- výkon státních podniků je dobrý,

3 Takto pojatý obecný cíl transformace však není všeobecně přijímán; např. L. Mlčoch uvádí, že pojetí transformace ,jako cesta od command economy k tržní ekonomice je zavádějící, zjednodušené a ideologizující klišé. Nejde o objevování trhu - jakoby až dosud žádný neexistoval - nejde dokonce ani o zcela novou tvorbu vlastnických struktur. Úkolem transformace a privatizace je nahradit méně formální entitlements právním systémem vlastnických práv a učinit existující trhy, až dosud neefektivně ztrnuté, nesoutěžní, monopolizující a diskriminující, trhy otevřenějšími, soutěžnějšími a výkonnějšími““ (Politická ekonomie č. 3/1994).

4 Klaus, V.: Česká cesta. Praha. Profile s. r. o., 1994. 
průřezech: $\mathrm{z}$ hlediska změn vlastnických struktur, $\mathrm{z}$ hlediska podnikového sektoru (míra jeho privatizace a změny struktury jeho řízení), z hlediska vývoje základních ukazatelů trhů a mezinárodního obchodu (otevřenost trhu, uvádění pravidel soutěže) a z hlediska finančních institucí (úroveň finanční discipliny aj.).

Za obsah transformace českého hospodářství budeme považovat ve shodě J. Laškem 5 systémové změny, institucionální změny a strukturální změny. Obsahem základních systémových změn je privatizace státního vlastnictví, liberalizace vnějších ekonomických vztahů, liberalizace cen a vnitřní směnitelnost. Podívejme se podrobněji na privatizaci.

\section{Privatizace}

Soukromé vlastnictví v ČR vznikalo různými způsoby: restitucemi do rukou původních vlastníků, transformací zemědělských družstev, malou privatizací (veřejnými aukcemi) a velkou privatizací (prodejem podniků domácím nabyvatelům, prodejem podniků zahraničním nabyvatelům a kupónovou privatizací). Lze souhlasit s následujícím hodnocením výsledku transformace vlastnických vztahů uvedených v Ročence HN již v roce 1999: „Ekonomický systém se změnil na tržní kapitalistickou ekonomiku s liberalizovanými cenami (až na nepatrnou část regulovaných cen), s dosud nedokonalými pravidly pro ekonomické chování tržních subjektů. V zásadě byly dobudovány instituce nezbytné pro fungování tržního mechanismu, ale jejich účinnost je oslabována nedokonalým právním rámcem. Stát má z hlediska vlastnických vztahů vliv jen na 39 organizací, i když často strategických, z toho 16 distribučních, které jsou ziskově orientované“. Výraznou změnu vlastnické struktury ukazuje to, že v r. 1989 soukromý sektor zaměstnával necelá $2 \%$ všech pracovníků v národním hospodářství, zatímco v roce 1998 to již bylo $75 \%$. To kladně hodnotí i Cardiffská zpráva z října 2003 (www.mfcr.cz/static/EU/Cardiff/cz/úvod.htm), z níž vyjímáme: „Nejvýznamnější strukturální změny přinesl radikální privatizační proces, který radikálně změnil vlastnické poměry zejména v podnikatelském sektoru. V současné době zbývá $\mathrm{k}$ dokončení privatizace 11 tzv. strategických společností s majetkovou účastí státu v elektroenergetice, ve spojích, rafinersko-petrochemickém průmyslu, hutnictví, dopravě a uhelném hornictví. Potenciální produkt české ekonomiky se podle našich propočtů v období 1996 - 2002 zvýšil o 11,5 \%. Toto tempo však nezaručuje dostatečně rychlou konvergenci české ekonomiky k úrovni zemí Evropské unie. Pro urychlení potenciálního růstu je zapotřebí implementovat strukturální reformy, které zlepší kvalitu, pružnost a transparentnost institucionálního a podnikatelského prostředí. Národohospodářská struktura ĆR se v širším mezinárodním srovnání vyznačuje stále ještě nadprůměrným podílem průmyslu, relativně nízkým podílem zemědělství, srovnatelným s ekonomicky vyspělými ekonomikami zemí EU a přetrvávajícím poněkud nižším podílem služeb. Nejvýznamnější strukturní změny přinesl radikální privatizační proces, který zásadně změnil vlastnické poměry zejména v podnikatelském sektoru. "Kromě významných privatizačních případů probíhá $\mathrm{v}$ různém stupni rozpracovanosti cca 90 případů privatizace majetku drobnějších státních podniků a majetkových účastí státu $\mathrm{v}$ menších akciových společnostech $\mathrm{v}$ hodnotě cca 3,5 mld. Kč s horizontem dokončení privatizace do roku 2005.

Privatizační proces byl doprovázen i růstem podílu podniků pod zahraniční kontrolou na všech organizacích s více než 100 zaměstnanci; ten se za toto období zvýšil o 18,5 procentních bodů. Mezi hlavní nedostatky současného podnikatelského prostředí v oblasti právní úpravy podnikání patří hospodářské praxi nevyhovující právní úprava úpadku podniků a způsobů jeho řešení a nevyhovující právní úprava zápisů do obchodního rejstř́íku,

5 Lašek, J.: Strukturální aspekty transformace ekonomiky ČR. Politická ekonomie č. 1/1998. 
která má za následek neúměrně dlouhé lhůty pro zápisy. Dále je třeba upravit již překonané pojetí zákoníku práce a nezbytná je i nová právní úprava nemocenského pojištění.

Pojednáváme-li o privatizaci, lze souhlasit s P. Chvojkou a K. Zemanem ${ }^{6}$, že „problematika privatizace nemůže být omezena pouze na změnu vlastnictví; konečným cílem je odpovídající restrukturalizace celé ekonomiky, zaměřená na zvýšení její výkonnosti a konkurenceschopnosti“. Uvedení autoři srovnávají transformaci v jednotlivých zemích SVE a konstatují, že „programy masové privatizace, které budponechaly kontrolu v rukou původních zaměstnanců či manažerů nebo ji rozpustily mezi držitele privatizačních kuponů (např. v ČR a SR) vyústily do pouze omezené restrukturalizace, restrukturalizace zejména pasivního typu“, zatímco „privatizace s dominující převahou „vnějšího“ vlastníka (zejména v kombinaci s př́livem přímých zahraničních investic, jako tomu bylo v případě Mad’ar ska) obvykle vyvolala hlubší, „aktivnější “ restrukturalizaci, nesenou novými investicemi a ústící do významných zlepš̌ení výkonů privatizovaného podniku““. ${ }^{1}$ Průběh ,„české privatizace" kritizuje i M. Myant , který české privatizaci vytýká dva základní chybné př́ístupy: důraz na kupónovou formu privatizace a důraz na kapitál české provenience. Uvádí, že alternativou této privatizaci mohl být jen prodej podniků zahraničním společnostem nebo celkově pomalejší průběh privatizace. K této kritice způsobu privatizace v ČR však lze uvést slova bývalého guvernéra Národní banky Josefa Tošovského: „Postaveni před výběr mezi pokračováním centrálně řízené ekonomiky po dlouhou dobu a rychlou privatizací, autoři privatizace vybrali menší ze dvou zel. V situaci, kdy stát držel většinu výrobních aktiv země, kdy lidé neměli potřebné peníze a zahraniční kupci nezaplavovali zemi, standardní privatizační metody nemohly být aplikovány. Dívaje se zpátky, neukazuje se, že výběr byl fundamentálně chybný, třębaže jasný zpětný pohled ukazuje, že některá rizika rychlé privatizace byla podceněna“. 8

\section{Liberalizace a strukturální změny}

Liberalizace znamenala odstranění všech překážek kapitalistickému podnikání a vytvoření podmínek pro fungování trhu, který se tak stává samoregulačním mechanismem ekonomiky. Liberalizace představovala rozbití centrálně řízené socialistické ekonomiky. Její rozhodující součástí byla liberalizace většiny výrobních a spotřebních cen, zavedení omezené (vnitřní) směnitelnosti domácí měny (k 1. 1. 1991), komplexní daňová reforma (k 1.1.1993), liberalizace vnějších vztahů (zrušení monopolu zahraničního obchodu), liberalizace pohybu zboží, peněz i kapitálu. Tím se od počátku vytvářely předpoklady pro budoucí vstup ČR do EU.

Protože transformace $\mathrm{v}$ podstatě spočívá ve výměně jednoho systému národního hospodářství (ekonomiky) za systém zcela odlišný, tj. spočívá v demontáži socialistického systému a ve vytvoření peněžně tržního (kapitalistického) systému, bylo nutné provést systémové změny. Provedení těchto systémových změn se v podstatě podařilo, resp. se daří; je ale nutné uvést, že celý proces transformace zpomalilo stálé odkládání privatizace bank a některých velkých podniků.

Systémové změny musí být zajištěny institucionálními změnami, tj. institucionálně a organizačně, což znamená, že v tomto procesu je nutno vytvořit nezbytný právní rámec, osvojit

6 Chvojka, P., Zeman, K.: Tendence dosavadního vývoje zemí střední a východní Evropy. Politická ekonomie č. $6 / 2000$.

7 Myant, M.: The Rise and Fall of Czech Capitalism. Development in the Czech Republic since 1989.

8 Tošovský, J.: Ten years on (some lessons from the transition). Prague economic papers 1/2001. 
si zvyklosti a normy chování (tj. celkovou kulturu) vlastní modernímu tržnímu hospodářství (ne „divokému“ kapitalismu) a také vytvořit hospodářské a jiné organizace vybavené nezbytnými pravomocemi. Jak ukazuje současnost v ČR, je zajištění těchto změn velmi obtížné a trvá poměrně dlouhou dobu. Pozitivním tlakem na tyto změny bylo přijímání norem EU. Všechny tyto transformační změny by měly vést i ke strukturálním změnám.

\section{Pod strukturálními změnami rozumíme}

- změny na makroekonomické úrovni, tj. změny sektorové (změny podílu tří hlavních sektorů - průmyslu, zemědělství a služeb), změny odvětvové (změny podílu jednotlivých odvětví, především průmyslových odvětví - strojírenství, hutnictví, chemie atd.), změny oborové struktury (změny podílu jednotlivých výrobních oborů i výrobků), dále změny vlastnických forem, změny velikosti podniků aj. (těmi se budeme zabývat v dalším odstavci); změny makroekonomické mají svůj počátek ve změnách zaměření podniků,

- změny na úrovni jednotlivých podniků (restrukturalizace vlastnických vztahů, restrukturalizace organizační, finanční, technologická, výrobková, aj.). Právě posledně zmíněná podniková restrukturalizace rozhoduje o tom, zda naše podniky budou konkurenceschopné, a to jak na tuzemském, tak i evropském trhu, resp. světovém trhu.

Ukazuje se, že transformace v ČR byla úspěšnější spíše v privatizaci než v restrukturalizaci: tvůrci ekonomické reformy na počátku 90. let předpokládali, že noví vlastníci sami budou své firmy restrukturalizovat, což se většinou stalo jen u firem se zahraniční účastí, které měly alespoň jednoho opravdového vlastníka. Velká část firem, majících rozdrobené vlastníky vzniklé v průběhu kupónové privatizace, konečného vlastníka často dosud nemá a jsou to většinou právě ony, které se nerestrukturalizovaly. Povětšinou jsou řizeny starým, „socialistickým“ managementem, jemuž podnikatelské chování a myšlení je cizí. Možná, že známé dva reformační polštáře (nízké mzdy a měnový kurz) byly příliš měkké na to, aby donutily podniky se restrukturalizovat. John Nellis, specialista Světové banky, v rozhovoru pro MF DNES 20. srpna 2002 ř́iká: „Co se týče podniků, Česká republika začala velmi dobře, na počátku transformace udělala řadu správných věcí. Ale nešla dost daleko. To platí především o vytváření podmínek pro restrukturalizaci. Podniky nestačily projít důležitými změnami, které by přinesly konkurenceschopnost, modernizaci a efektivnost. V Polsku a Mad'arskucož jsou pro vás dva největší regionální soupeři, firmy prošly hlubší restrukturalizací. Zbavovaly se starých výrobních postupů, snižovaly náklady a zvyšovaly efektivitu, což s sebou také přineslo daleko vyšší míru nezaměstnanosti. Když u vás byla tříprocentní nezaměstnanost, zdálo se, že Češi postupují správně. Nebyl to ale ukazatel úspěchu, nýbrž důkaz, že podniky neprocházejí restrukturalizací jako v Polsku a Mad’arsku“.

\section{Restrukturalizace a revitalizace $v$ teorii}

Vysvětleme nejprve proces restrukturalizace. Restrukturalizací obvykle rozumíme změnu struktury určitého organismu; jde-li o národní hospodářství, hovoříme o makroekonomické restrukturalizaci, jde-li o podnik hovoříme o mikroekonomické (podnikové) restrukturalizaci. V této části se nejdřive budeme zabývat restrukturalizací podniků, následně potom restrukturalizací národního hospodářství. 


\subsection{Restrukturalizace podniků}

Samotný termín restrukturalizace se používá ve dvou významech - jako neustálé přizpůsobování vnitřní struktury podniků (organizací) měnícímu se okolí (jde většinou o dílčí podnikové změny), nebo jako radikální, systémově ucelená, komplexní změna struktury určité organizační jednotky (podniku, závodu, holdingu apod.). Např. J. Veber charakterizuje restrukturalizaci jako „změnu základní struktury, která v prŕípadě organizací se dotýká změny výrobní náplně, zdrojů organizace, jejich provázanosti a využití, a může být doprovázena změnami organizační architektury“. Správně zdůrazňuje, že na ni nelze pohlížet jako na ojedinělou záležitost, uskutečňovanou čas od času, ale pravidelnou součást manažerských aktivit, jejichž smyslem je zabezpečit, aby vnitřní chod organizace nebyl brzdou jejího vývoje.

Prvé pojetí (neustálé přizpůsobování) je označováno jako obranná restrukturalizace, druhé pojetí (radikální, komplexní změna) bývá označováno jako strategická restrukturalizace. Ta ve své komplexnosti podle L. Vodáčka zahrnuje změny ${ }^{10}$

- strukturní skladby výrobního programu a s ní sladěné inovace ve strukturách,

- výrobní (změny struktury výrobně technické základny),

- funkcionální (změny struktury funkcí společenské dělby práce),

- informační (změny struktury používaných informačních systémů),

- organizační (změny struktury právních forem a vnitřního uspořádání pravomoci a odpovědnosti),

- personální (změny struktury profesní a kvalifikační skladby pracovníků),

- finanční (změny struktury aktiv a pasiv).

Strategická restrukturalizace by měla vycházet ze zvolené podnikatelské strategie firmy (z podnikatelského „business“ plánu). Tato restrukturalizace byla rozhodující pro celkové změny $\mathrm{v}$ ekonomice, především však pro změnu odvětvové struktury (růst podílu terciální sféry) a pro přeorientaci českého zahraničního obchodu. A protože pro velkou část českých podniků to znamenalo obrovský pokles objemu výroby (pokles pod - z teorie známý - break even point), staly se tyto podniky neživotaschopné a mnoho z nich stálo nebo stojí před úpadkem. Zachránit je může to, čemu říkáme revitalizace, tj. oživení (sanace) podniku. Tou tedy rozumíme všechny aktivity směřující k obnovení, resp. posílení všech činitelů ovlivňující zdravý a efektivní vývoj podniku. Ta se zatím spojuje více s finanční restrukturalizací, tj. se změnami na straně aktiv a pasiv finanční bilance (rozvahy) podniku, někdy i s organizačními změnami. $\mathrm{V}$ podmínkách českého průmyslu jde převážně o oddlužení, kapitalizaci pohledávek, změny právně organizačních forem podnikủ aj.

Podniky, které se nepřizpůsobily změněným podmínkám po roce 1989, mají v současné době potíže, mnohé se dostaly do finanční tísně a je na ně uvalen konkurz, mnohé jsou v likvidaci. Nutno zdůraznit, že kritériem toho, zda určitý podnik má budoucnost, musí být trh, tj. zájem investorů (většinou zahraničních) o jeho koupi. A zde se ukazuje, že zájem o podniky, jejichž hodnota (tržní hodnota) je nulová, je minimální. Tržní hodnota podniku (k tomu viz dále) je totiž dána sumou budoucích diskontovaných čistých výnosů (cash flows) a ta - je-li nulová nebo záporná - nevyvolá zájem o jeho koupi. A pokud takovýto

9 Veber, J. a kol.: Management. Základy, prosperita, globalizace. Praha, Management Press, 2000. ISBN 80-7261-029-5.

10 Vodáček, Leo: Úkoly restrukturalizace českých podniků. Politická ekonomie č. 5/1998. 
podnik má „vlastníka“, pak jeho další fungování stravuje jím původně vložený kapitál, což si delší dobu skutečný soukromý vlastník nemůže dovolit. Pokud je vlastníkem stát, může podnik přežívat jedině $s$ jeho pomocí. Historie však učí, že stát moc dobrým vlastníkem není. Státní úředníci nemohou trh nahradit a jejich činnost v této oblasti může být jen náhradním řešením. Je jasné, že současná česká vláda se snaží do řízení podniků zasahovat více, než vlády předešlé (těm by se zase mohlo vytknout, že pro podnikání nevytvořily potřebné prostředí a nezbytný tlak na jejich restrukturalizaci). Činností vlády v této oblasti se budeme podrobněji zabývat v následujícím odstavci.

\subsection{Restrukturalizace národního hospodářství}

K restrukturalizaci firem a tím i celé ekonomiky v zemích s tržní ekonomikou dochází neustále: firmy přizpůsobují strukturu svých činností, aktiv i pasív měnícím se podmínkám na trhu zboží i na finančním trhu. Firmy v EU, v USA i v ostatních zemích mění strukturu svých zdrojů (podíl vlastního kapitálu, prioritních akcií, dlouhodobých půjček a obligací, krátkodobých půjček a cenných papírů, podíl leasingu apod.), stejně jako strukturu své činnosti a aktiv (hledají nové segmenty trhu a nové podnikatelské činnosti, kterým přizpůsobujî́ svá aktiva). Restrukturalizace je proces spojený s obdobím moderního kapitalismu. Počet i rozsah restrukturalizačních akcí se však na počátku 70. let podstatně zvýšil a přitom se podstatně rozšírily formy restrukturalizace, od původně převažující fúze (sloučení, v angl. terminologii merger) a koupi (akvizice) k řadě dalších, které si ukážeme v kapitole 8.

Restrukturalizace probíhala a probíhá i v naší ekonomice. Má však do jisté míry charakter a význam odlišný od obdobných procesů probíhajících ve světové ekonomice. Je totiž (resp. měla by být) součástí transformace naší ekonomiky z centrálně řízené na ekonomiku tržní. Součástí tohoto procesu měly být radikální změny podílu jednotlivých sektorů národního hospodářství, změny odvětvové, oborové struktury průmyslu, stejně jako změny ve výrobkové (sortimentní) náplni podniků. Slovo restrukturalizace se v uplynulých letech dostalo do povědomí široké veřejnosti v souvislosti s vládními programy restrukturalizace a revitalizace. Transformace naší ekonomiky předpokládala, že restrukturalizaci nejlépe provedou noví vlastníci, kteří vzejdou z privatizace. Tam, kde z privatizace vzešli skuteční vlastníci, většinou restrukturalizace proběhla. Nejznámějším příkladem je automobilka AutoŠkoda Mladá Boleslav. Je to ale i řada dalších podniků, které se v současné době úspěšně rozvíjejí; jmenujme alespoň Karosu Vysoké Mýto, Barum Continental Otrokovice, CEZ a. s.

Česká ekonomika po roce 1989 vstupovala do transformačního období se značnými strukturálními odlišnostmi od zemí s vyspělou tržní ekonomikou. Šlo především o předimenzovaný průmysl, zejména těžký a nedostatečně rozvinutý terciální sektor (služby). Dále o zanedbanou dopravu a telekomunikace, vysokou administrativní koncentraci výroby, nízkou produktivitu práce a vysokou nákladovost produkce, technickou zaostalost výrobků i výrobních postupů. Problematická byla jednostranná orientace zahraničního obchodu na bývalý SSSR a socialistické a rozvojové země. Restrukturalizace (makroekonomická) probíhala v několika směrech; ty odpovídaly předchozímu vývoji, zejména deformacím konkurenčního prostředí, rigidním cenám, dlouhodobé orientaci zahraničního obchodu na východní trhy a také způsobu regulace trhu práce.

Stav na počátku 90. let charakterizuje vysoká zaměstnanost v tzv. výrobních odvětvích a zaostávání v rozvoji služeb. 
Tab. č. 1: Zaměstnaní v národním hospodářství v \%

\begin{tabular}{|l|c|c|c|}
\hline \multicolumn{1}{|c|}{ Sektor } & ČR 1990 & EU 1990 & ČR 2002 \\
\hline Zemědělství a lesnictví & 15,3 & 6,7 & 4,6 \\
\hline Průmysl a stavebnictví & 41,9 & 33,1 & 39,5 \\
\hline Služby & 42,8 & 60,2 & 55,9 \\
\hline Celkem & 100,0 & 100,0 & 100,0 \\
\hline
\end{tabular}

Transformační proces vnesl do struktury české ekonomiky podstatné změny. Byl to důsledek adaptace ekonomiky na změny vlastnických struktur podniků, na reorientaci zahraničního obchodu a vznik statisíců nových firem hlavně v sektoru služeb.

Nejvýraznější přesuny pracovních sil se odehrály již v prvních třech letech transformace, kdy průmysl a zemědělství přišly o 500 tisíc pracovních míst, což v průmyslu snižilo zaměstnanost o $13 \%$ a v zemědělství o $47 \%$. Charakteristickým rysem tohoto období bylo, že toto masové snížení zaměstnanosti se prakticky jen nevýznamně přelilo do růstu nezaměstnanosti a bylo především tlumeno snížením ekonomické aktivity osob v poproduktivním věku a rozvojem služeb. V období 1990 až 1995 se ve službách vytvořilo celkem 380 tisíc nových pracovních míst. Po roce 1995 se tempo změn struktury ekonomiky zpomalilo. Zaměstnanost $\mathrm{v}$ průmyslu se $\mathrm{v}$ posledních letech stabilizovala zhruba na úrovni 1,124 mil. pracovníků. Uvnitř průmyslu je nejmarkantnějším rysem pokles podílu strojírenství, které ztratilo svou dřívější dominantní pozici. Zaměstnanost v zemědělství se ustálila okolo 193 tisíc pracovníků, avšak ani to nelze považovat za konečný a optimální stav. Růst zaměstnanosti v sektoru služeb stále pokračuje, i když v daleko mírnějších tempech a víc s ohledem na stav konkurenčního prostředí. V současné době zaměstnává sektor služeb již 2,6 mil. pracovníků. Ve srovnání s vyspělými zeměmi EU je zaměstnanost v průmyslu dosud předimenzována (v r. 2002 ČR 39,5 \%, EU 27,5 \%) a naopak sektor služeb ještě nedosahuje proporci typickou pro země EU (ČR 55,9 \%, EU $69 \%$ ).

Změnila se i velikostní struktura podniků. V roce 1989 převládaly velké podniky a zcela chyběly střední a drobné podniky, přitom jejich úloha v moderním hospodářství je zcela nepřehlédnutelná. Iv tomto směru došlo k výrazné změně, za posledních 10 let vznikly statisíce malých firem. Např. k 31. 12. 2002 z celkového počtu 2223745 firem jich 2139 076, tj. 96,06 \% procent, mělo maximálně pět zaměstnanců. Malé a drobné firmy absorbovaly velkou část pracovníků uvolněných především z průmyslu, a tak brzdily růst nezaměstnanosti. To však, jak ukazuje J. Chlumský ${ }^{11}$, mělo i negativní vliv: podle něj vznik drobných podniků, především ve sféře maloobchodu, které na nynější úrovni světového vývoje nemají téměř žádnou šanci dlouhodobého přežití, urychlil pronikání zahraničních řetězových maloobchodních sítí, které na našem vnitřním trhu umistují zboží svých obvyklých zahraničních dodavatelů, což přispívá ke zhoršení naší obchodní bilance. Podle mého názoru však lze tvrdit, že převažují kladné stránky vzniku malých a drobných firem, především pak ve službách, výrobě, stavebnictví; nutno připomenout, že tzv. střední třída je většinou i zárukou politické stability státu. O situaci v oblasti maloobchodu vypovídá i dotazníkový průzkum, provedený Protimonopolním úřadem SR v roce $2000^{12}$. Z odpovědí dodavatelů obchodních řetězců vyplynulo, že

- všechny řetězce si vynucují vstupní poplatky za zaevidování (od 10 tis. do 100 tis. Sk),

11 Chlumský, J.: Ekonomická konvergence mezi ČR a EU. Acta Oeconomica Pragensia 6/2002.

12 Podrobněji viz Gajdoš, Josef: Obchodné refazce hypermarketov a maloobchodná siet̉na východnom Slovensku. In Ekonomika firiem 2003 (sborník z mezinárodní konference), Podnikovohospodárská fakulta Ekonomické university v Bratislave). 
- všechny řetězce požadují poplatky za uvedení jednotlivých výrobků (od 2 tis. Sk do $8 \%$ obratu),

- některé řetězce žádají poplatky za umístění výrobku na výhodném místě,

- řetězce požadují další poplatky za zveřejnění výrobku v letáku,

- řetězce prodlužují termín splatnosti faktur až na 60 dní aj.

Představitelé většiny řetězců tyto praktiky potvrzují, pokládají je však za standardní obchodní zvyklosti, které nejsou v rozporu s obchodní etikou; neliší se od marketingové politiky uplatňované v zahraničí. I dodavatelé přiznávají, že spolupráce s řetězci jim přináší nesporné výhody, především velký objem dodávek; nevýhodou jsou zvýšené náklady na logistiku (řetězce $\mathrm{v}$ důsledku malých skladovacích prostor požadují menší velikost dodávek a tím i jejich větší počet). Dodavatelé nepovažují praktiky řetězců za nepřiměřené, nebot převažuje jejich kladný vliv na postavení dodavateli̊. Na základě výsledků průzkumů upustil Protimonopolní úřad SR od regulačních zásahů, které by zřejmě přinesly zvýšení cen, omezily by konkurenci a vyžádaly by si velké monitorovací náklady.

Převažující podíl zahraničního obchodu s bývalým SSSR a bývalými socialistickými zeměmi, který existoval až do počátku 90 . let, bohužel nevyvíjel potřebný tlak na výrobkové inovace, technické parametry a jakost výrobků a adaptabilitu výrobců na měnící se tržní poměry. Propad východních trhů po roce 1989 postavil řadu našich podniků před obtížnou situaci a vyvolal tím i rozsáhlé změny v teritoriální struktuře našeho zahraničního obchodu. Podniky, které tuto restrukturalizaci nezvládly, mají většinou značné problémy dodnes. Strukturální změny vývozu ČR zachycuje tabulka 2 .

Tab. č. 2: Teritoriální struktura vývozu ČR (v \%) vypočteno podle Statistické ročenky 2003

\begin{tabular}{|c|c|c|c|}
\hline Rok & $\begin{array}{c}\text { Evropské země s tranzitivní } \\
\text { ekonomikou a SNZ }\end{array}$ & Vyspělé tržní ekonomiky & Rozvojové země \\
\hline 1990 & 49,37 & 45,13 & 10,50 \\
\hline 2003 & 21,24 & 75,24 & 3,52 \\
\hline
\end{tabular}

Faktem však je, že vnitřní struktura průmyslu, našeho rozhodujícího odvětví, se nezměnila v žádoucím směru. V období poklesu objemu produkce, který transformaci doprovázel, a který byl - aniž bychom hodnotili jeho rozsah - objektivně nutný (omezení a zastavení výroby nepotřebných, zastaralých a neprodejných výrobků apod.), nastal největší pokles ve zpracovatelském průmyslu. Při poklesu objemů produkce (v rámci národního hospodářství při recesi) je restrukturalizace obtížnější a dražší; i to je příčinou potíží řady podniků až do dnešních dnů.

\section{Průběh restrukturalizace $v$ českém průmyslu}

\subsection{Plány vlády}

V roce 1998 Ministerstvo průmyslu a obchodu v čele s ministrem Miloslavem Grégrem navrhlo Program revitalizace a restrukturalizace průmyslových podniků nacházejících se v přechodných obtížích. Spolu s ním byly předloženy vládě další dokumenty, např. Návrh koncepce průmyslové politiky a Návrh zásad programu restrukturalizace jednotlivých odvětví průmyslu. Podle Programu revitalizace se měla akcionářská práva převést na 
stát, respektive na ministerstvo. Stát, státní banky by podle tohoto plánu daly peníze na revitalizaci, kterou by prováděl dosavadní management. Pokud by se revitalizace povedla, akcie, nebo jejich část, by se převedly na původní majitele. Toto pojetí je podle mého názoru v hlubokém rozporu s principy tržního hospodářství, především s tím, že vlastníci a jimi ustavený management nesou plnou majetkovou odpovědnost za důsledky svého jednání. I samotná kritéria Programu pro výběr podniků byla velmi mlhavá (např. jedním z kritérií výběru byl „multiplikační efekt“ pro odvětví nebo výrobní obor, jiným „naléhavost problému“). Tento program nebyl přijat a jako jiné řešení byla v květnu 1999 ustavena Revitalizační agentura, která měla revitalizovat vybrané podniky.

Hlavním úkolem Revitalizační agentury bylo realizovat program vlády revitalizace (program na záchranu, oživení) vybraných velkých průmyslových podniků. Byla založena Konsolidační bankou jako jediným zakladatelem. Jejím úkolem bylo vybírat portfolio společností a zajistit odkup jejich dluhů resp. vlastního jmění (dnes vlastního kapitálu) od českých komerčních bank nebo jiných institucí za spravedlivou tržní hodnotu (fair market value), vybírat životaschopná aktiva společností, které jsou v bankrotu a zajistit jejich prodej za spravedlivou tržní hodnotu. Dále měla řídit restrukturalizaci ve vybraných velkých průmyslových korporacích, které jsou ve finanční tísni, jednat s bankami o finanční restrukturalizaci, dohlížet a kde je to nutné nahradit stávající management, restrukturalizovat činnost podniků tak, aby se usnadnil jejich prodej nebo vstup strategického partnera, prodej podniků uskutečnit včasným a transparentním způsobem. Pravidla pro výběr podniků pro revitalizaci stanovila vláda v prosinci 1998; mělo jít o zadlužené podniky, které mají více jak 2000 pracovníků, jejich nákup od tuzemských podniků přesahuje 1 mld. Kč, klasifikované dluhy u KoB, komerčních bank a ČS přesahují 3 mld. Kč a jejich provozní zisk je kladný.

Podle předběžného indikativního seznamu vlády šlo o 59 podniků (uved'mety nejznámější: Adamovské strojírny, Aero Vodochody, ČKD Dopravní systémy, ČKD Vagonka Studénka, Hedva, Metra Blansko, Spolana, Transporta, Třinecké železárny, Zbrojovka Brno, Zetor, ŽDB aj.).

\subsection{Průběh revitalizace podle vládního scénáře}

Prováděním konkrétních kroků a poradcem Revitalizační agentury byl pověřen správce - konsorcium Lazard-Latona. Jeho výběr proběhl konkurzem, nebot muselo jít o firmu s bohatými zkušenostmi v revitalizaci podniků v jiných zemích. Jak je uvedeno výše, cílem Revitalizační agentury mělo především být vybírání společností pro revitalizaci, zajištění odkupu jejích dluhů, respektive vlastního kapitálu od českých komerčních bank nebo jiných institucí, restrukturalizovat činnost podniků a ozdravit je a jako zdravé subjekty je výhodně prodat (tj. najít po ně potenciálního kupce a strategického partnera).

Již v průběhu jednoho roku se úloha Revitalizační agentury podstatně změnila. Hlavní změna spočívala v tom, že z vlastníka a realizátora revitalizace průmyslových podniků se v podstatě stal pouhý poradce managementu podniků, resp. zprostředkovatel některých restrukturalizačních kroků. Revitalizační agentura od svého vzniku hospodařila se ztrátou (celková ztráta za dobu její činnosti je 233 mil. Kč). K 1. únoru 2004 předčasně ukončila svou činnost s tím, že revitalizační program budou zajištovat přímo dosavadní správci agentury, tj. společnosti Latona a Lazard. Ty by měly dokončit prostřednictvím nově založené firmy Odien Restructuring Services revitalizaci Zetoru, Tatry, Škody a Hutních montáží Ostrava. Sama Revitalizační agentura nedokončila ani jeden projekt. Vinu na tom zřejmě má i vláda, která v rozporu s přijatým scénářem revitalizace rozhodla, že Revitalizační agentura nebude vykupovat od bank pohledávky vybraných podniků a získávat je tak 
do svého majetku, ale že přejdou do Konsolidační banky. Ta byla založena v únoru 1991 a jejím úkolem bylo řešit některé důsledky centrálně plánované ekonomiky (převzala např. pohledávky za úvěry na tzv. trvale se obracející zásoby). Po rozpadu Československa zahájila činnost Konsolidační banka Praha; její aktivity se v průběhu času rozšiřovaly a nakonec se stala hlavním finančním manažerem vybraných rozvojových projektů, které prováděl stát, podílela se na očistě portfolia velkých českých bank aj.

V roce 2001 byl v podstatě celý původní vládní program transformace ukončen. Konsolidační banka pozbyla bankovní licenci a byla transformována v Českou konsolidační agenturu. Ministerstvo průmyslu navrhlo dva nové programy - Exit a Rozvaha, které mají být dotovány ročně cca 20 mld. Kč. Program Exit spočívá v prodeji pohledávek, které má Konsolidační banka vůči podnikům. Program Rozvaha má nejprve podniky restrukturalizovat, poté vyměnit pohledávky za akcie podniku a vytlačit pưvodního vlastníka. O výběru podniků do obou programů bude rozhodovat tzv. investiční rada, kterou bude podobný orgán jako u Revitalizační agentury byl správce. Jeho členy jsou úředníci hospodářských ministerstev, kteří podle analýz hospodářské situace podniků rozhodnou o jejich zařazení do programů. V režii Ministerstva průmyslu a obchodu vznikla i další agentura - Czechindustry, která má vyhodnocovat restrukturalizační programy vypracované managementem podniků a v př́ípadě kladného hodnocení poskytnout dotaci ve výši $10 \%$ nákladů restrukturalizace. Posledním programem, který opět předložil ministr Grégr, byl Plán radikálního zvýšení výkonnosti českého průmyslu cestou masivní restrukturalizace a revitalizace, zkráceně označovaný jako „velký třesk“. Jeho realizace měla zajistit více jak $6 \%$ roční růst HDP. Výsledkem restrukturalizace prováděné za „státní “ peníze (projekt počítal s vynaložením 265 mld. Kč), mělo být zeštíhlení a modernizace podniků; potom má následovat jejich prodej strategickým partnerům.

Jak tedy hodnotit činnost Revitalizační agentury? Jeden ze zakladatelů Revitalizační agentury Miroslav Zahradník uvedl: „Agentura ušetřila státu moře peněz. Do podnikủ se nelily bez jakýchkoliv opatření obrovské peníze, ani žádná z vybraných firem neskončila v konkursu, který by znamenal pro stát obrovské ztráty“ (MF Dnes 5. 2 . 2001). To, že vybrané firmy (Zetor, Vítkovice) přežily, kladně hodnotí i vedení odborů. V průběhu roku 2000 se podařilo odvrátit konkurz Vítkovic, v roce 2001 Železáren a drátoven Bohumín a Válcoven plechu Frýdek-Místek (všechny tři společnosti by měly být restrukturalizovány podle Národního plánu restrukturalizace českého ocelářského průmyslu, který byl schválen Evropskou komisí v roce 2003). Proběhla privatizace plynárenského průmyslu podle vládního programu z roku 2000 (strategickým vlastníkem plynárenského sektoru v Ćeské republice je od roku 2002 německá společnost RWE GAS AG), v ř́ijnu 2000 vláda schválila scénář privatizace elektroenergetiky (dosud se jej nepodařilo realizovat), několik společností (ke konci roku 200317 podniků) je restrukturalizováno prostřednictvím programů Exit a Rozvaha o nichž pojednáme dále, (výběr podniků provádí Investiční rada vlády ČR). Řadě i velkých firem však konkurz stále hrozí. V lednu 2003 schválila vláda Operační program Průmysl a podnikání pro léta 2004 až 2006, jehož cílem je přispět ke zvýšení konkurenceschopnosti průmyslu.

Restrukturalizaci v pojetí posledních dvou vlád neprovádějí tedy vlastníci, ale ministerští úředníci.

Poslední snahou vlády o řízení revitalizace a restrukturalizace v českém hospodářství je zřízení České konsolidační agentury. Ta je finanční institucí nebankovního typu, za jejíž závazky ručí stát. Byla zrrízena zákonem 239/2001 Sb. k 1. 9. 2001 a má zaniknout k 31. 12. 2011 bez likvidace; její práva a závazky přebere stát (Ministerstvo financí ČR). Jejím předchůdcem byla Konsolidační banka Praha. 


\subsection{Byla kritéria a metody hodnocení podniků správně zvolena?}

Otázkou zůstalo, zda kritéria výběru podniků stanovená vládou, byla ta pravá. Podle našeho názoru by se měl výběr podniků řídit těmito pravidly ${ }^{13}$ :

1. pomoc státu se může týkat pouze několika klíčových podniků, se kterými jsou propojeni významní dodavatelé a na nichž je závislá zaměstnanost v určitém regionu,

2. podniky, které budou vybrány, musí mít marketingově strategický program, který prodejem konkurenceschopných výrobků na světovém trhu zajistí návratnost vynaložených prostřredků,

3. př́děl prostředků by měl být posuzován jako strategická investice a hodnocen osvědčenými metodami oceňování investičních projektů, resp. metodami oceňování podniků,

4. protože dosavadní vlastníci a management se neosvědčili, nesmí se pomoc státu zásadně týkat jich,

5. restrukturalizace by měla být spojena s důslednou privatizací, především s vyhledáním strategického partnera, který má již zajištěn trh pro své výrobky. Restrukturalizaci by měli zajištovat noví vlastníci a nový management - př́ímé rízení Revitalizační agenturou by mělo být zcela výjimečné.

Pokud jde o metody oceňování investičních projektů a podniků, jsou dostatečně teoreticky propracovány i v naší odborné literatuře a dostatečně ověřeny v naší hospodářské praxi. Připomeňme jen, že nejpoužívanější metodou oceňování je metoda diskontovaného volného cash flow (DFCF), která $\mathrm{z}$ hlediska teorie je základní metodou oceňování; v praxi je nejvíce používaná v USA a Velké Británii, v poslední době i v zemích EU včetně naší republiky. Tato metoda má několik variant (metoda „entity“ - zjištuje hodnotu celého podniku, metoda „equity“ - zjištuje hodnotu majetku akcionářu, metoda APV - metoda upravené současné hodnoty podniku, která je vypočtena jako součet současného hodnoty cash flow plynoucí z vlastního kapitálu a současné hodnoty plynoucí z dluhového financování, dividendové metody aj.; existuje i několik postupů (jednofázová - počítá s hodnotami cash flow jednotlivých roků, dvoufázová - počítá obvykle s hodnotami budoucích pěti let a hodnotou perpetuity pro zbytek životnosti, tř́fázová metoda (období existence podniku rozděluje na období mimořádného růstu, přechodné období a období stabilního růstu. Kromě metody DFCF lze použít i metodu kapitalizovaných čistých výnosů (zisků) nebo kombinovanou metodu. Vstupní hodnoty pro tuto metodu bychom měli zjistit ze strategického marketingového plánu. U podniku, který přichází v úvahu pro sanaci (revitalizaci), nebotneprosperuje, pracuje se ztrátou a je víc mrtvý než živý, je nutné zjistit i tzv. likvidační hodnotu, tj. hodnotu (množství peněz), která se získá prodejem jednotlivých aktiv podniku. Zjistí se jako suma prodejních cen jednotlivých majetkových složek podniku prodávaných individuálně. Postup výpočtu je podobný substanční metodě. Musí se však přihlédnout k tomu, že neplatí princip pokračujícího podniku (viz dále) a že cena jednotlivých aktiv je závislá i na zájmu kupujících (např. některé části majetku jsou zcela neprodejné). Důležitý je vztah likvidační hodnoty a hodnoty zjiššcéné oceněním podniku, který by po revitalizaci pokračoval ve své činnosti (to je tzv. princip going concern, hodnota se nazývá going concern value). Pro rozhodnutí, která z těchto hodnot, tj. zda hodnota likvidační nebo hodnota pokračující podniku, je spravedlivou tržní hodnotou (FMV - fair market value), platí:

- je-li hodnota DFCF, vypočtená na základě realizace revitalizačního plánu (sanačního plánu) nižší, než hodnota likvidační, nevyplatí se podnik revitalizovat; měli bychom přihlédnout i $\mathrm{k}$ hodnotě goodwillu,

13 Rozhovor autora této kapitoly v týdeníku Ekonom č. 43/1999. 
- je-li hodnota DFCF vyšší, než hodnota likvidační, revitalizace se vyplatí a plán sanace by měl být realizován.

\subsection{Strukturální politika vlády $\mathrm{v}$ teorii}

Naprostá většina autorů učebnic ekonomie se shoduje na tom, že v současné době má vláda (u nás se tradičně používá slovo „stát“) důležitou úlohu v řízení společnosti (government control). Nejde jen o tradiční sféry pưsobnosti vlády jako jsou veřejné služby (obrana, policie, požární ochrana, administrativa, justice), fiskální a monetární politika, legislativa, přerozdělování národního důchodu prostřednictvím daní a vládních výdajů, ale i oblast aktivního vytváření struktury národní ekonomiky. Je nutné vidět, že to mohla být jen vláda, která svou politikou musela vyplnit vakuum v období po odstranění př́ímého řízení ekonomiky státem a vznikem vyvinutého tržního mechanismu.

Proto v souvislosti se strukturálními změnami se nastoluje otázka úlohy strukturální politiky vlády (státu). V teorii se někdy rozlišují tyto př́stupy ke strukturální politice ${ }^{14}$ :

- liberální - úloha strukturální politiky se omezuje na zlepšování všeobecného rámce, v němž se odehrávají producentské aktivity a spotřebitelské volby a na podporu automatického procesu strukturálního přizpưsobení, který vyžaduje kvalitní infrastrukturu, profesně přizpůsobenou pracovní sílu, přístupnost kapitálu a úvěru a ekonomicky racionální fiskální systém,

- podpůrný - předpokládá některá omezení trhu jako alokačního mechanismu,

- aktivní - prosazuje širší vládní zásahy, např. tlumení úpadku nekonkurenceschopných odvětví a firem, ochrana před vnější konkurencí a

- strategický - vládní zásahy se zaměřují na strategické plánování a intervencionalistická opatření.

Lze souhlasit s hodnocení Cardiffské zprávy, že současná vláda provádí aktivní průmyslovou, zemědělskou a proexportní politiku s jejím výrazně deficitním financování; kdybych ji měl do některé $\mathrm{z}$ výše uvedených strukturálních politik zařadit, tak asi do aktivní politiky. Svědčí o tom např. politiky, které zpracovalo Ministerstvo průmyslu obchodu pro budoucí léta, např. střednědobou resortní politiku, průmyslovou politiku, energetickou politiku, surovinou politiku, politiku podpory středního a malého podnikání, proexportní politiku, spotřebitelskou politiku, koncepci výzkumu a vývoje. Strategický, dlouhodobý plán (politika) však chybí.

Podle snahy o urychlení nebo zpomalení strukturálních změn se rozlišují tři typy strukturální politiky vlády:

- akcelerační,

- decelerační a

- neutrální.

Tato problematika přesahuje rámec této práce; bliže se s ní lze seznámit v citované publikaci. O jakou restrukturalizaci v současných českých podmínkách půjde, ukazuje J. Heczko ${ }^{15}$. Mělo by jít o restrukturalizaci věcnou (změna materiálních, technologických

14 Kadeřábková, A.: Strukturální politika - trh nebo státní zásahy? Politická ekonomie č. 3/1998.

15 Hezcko, J.: Ekonomická reforma v širších souvislostech. Acta Oeconomika Pragensia č. 3/1999. 
parametrů výroby a směny), celkovou (změna výrobních i nevýrobních činnostív ekonomice jako celku), hlubokou (cílem je dosažení technologické úrovně informačního věku), restrukturalizaci probíhající v období poklesu či stagnace. Strategickým rozhodnutím bude volba způsobu restrukturalizace naší ekonomiky: budbude živelný s minimem vlastních zásahů (liberální politika), nebo budou využity možnosti státní (vládní) regulace (moderní státní kapitalismus). Autor článku se přiklání $\mathrm{k}$ druhému způsobu, o kterém předpokládá, že nastartuje ekonomický růst. V každém případě měly naše podniky počítat s tím, že se po vstupu ČR do EU některé rozhodovací pravomoci přesunou na orgány EU.

Uvádí se, že česká ekonomika od roku 1990 prošla těmito třemi, resp. čtyřmi fázemi:

- transformační recese (1990 - 1992), charakterizována snahou o rychlý přechod od centrálního řízení $\mathrm{k}$ tržnímu hospodářství; je to období rozpadu RVHP a ztráty řady trhů, poklesem HDP o 15 až $20 \%$;

- hospodářské oživení (1993 1996), období růstů ekonomiky považované za český hospodářský zázrak; je to období masové privatizace (dvě etapy kupónové privatizace) doprovázené restrukturalizací, ale v zárodku i nezdravými tendencemi (růst domácí poptávky kryté dovozem - růst deficitu běžného účtu platební bilance, nedostatečné právní zabezpečení transformace);

- hospodářská stagnace a recese (1997 - 1999), která si vyžádala přímé zásahy vlády do ekonomiky (balíčky opatření v roce 1997);

- období pomalého růstu 2000 - 2003 (v průměru $3 \%$ ročně, které nezaručuje rychlé přiblížení české ekonomiky k úrovni zemí EU), období růstu nezaměstnanosti, snižování úrokových sazeb.

Ukazuje se, že současná česká vláda se vysoce angažuje a i v budoucnosti se hodlá angažovat $v$ restrukturalizaci průmyslu a jeho podniků, že se hodlá stát jejím hlavním organizátorem a financiérem. Restrukturalizaci v pojetí posledních dvou vlád neprovádějí tedy vlastníci ale ministerští úředníci. Svou činnost bude mít vláda usnadněnu v případě, že pro českou ekonomiku skončila recese a nastalo období růstu (je totiž obecně známo, že restrukturalizace snáze probíhá při růstu ekonomiky než při její stagnaci), čemuž nasvědčují výsledky posledních dvou let. Další vývoj české ekonomiky je ovšem závislý převážně na vývoji v EU, především v Německu; rovněž není jasný vliv událostí 11. září 2001 na další vývoj světové ekonomiky.

\section{Co dříve? Restrukturalizace nebo privatizace?}

V tomto stručném pojednání o restrukturalizaci ještě zbývá vyjádřit se ke sporu, který probíhá dosud: kdo provádí restrukturalizaci a zda restrukturalizace měla předcházet privatizaci či naopak. V programovém prohlášení české vlády v létě 1992 (HN 23. 7. 1992) se píše: „V zájmu co největšího urychlení restrukturalizace ekonomiky bude vláda vytvářet podmínky pro co nejsnazší pohyb a přelévání výrobních zdrojů na mezistátní, teritoriální i podnikové úrovni, bez čehož není restrukturalizace ani ekonomický růst možný. Vláda samozřejmě nebude vznik těchto procesů př́mo organizovat a zajištovat, ale soustavou vhodných opatření bude iniciovat jejich rozvoj a fungování. Nebude se však podílet na socializujících praktikách státních intervencí, které by se pod hesly strukturální či průmyslové politiky pokoušely omezovat či dokonce zcela nahradit přirozené tržní procesy. Za hlavní nástroj potřebných strukturálních změn v české ekonomice pokládá vláda privatizaci a rozvoj tržních vztahů. S výjimkou vybraných případů nebude vláda provádět re- 
strukturalizaci, protože tu musí uskutečnit jejich noví vlastníci.“ Nechceme tvrdit, že předešlé vlády udělaly pro restrukturalizaci všechno, co měly nebo mohly udělat. Vlastní zkušenosti nás však vedou k tvrzení, že v podnicích, kde privatizace přinesla skutečné vlastníky, a tito vlastníci vytvořily kvalifikované statutární orgány, které ustavily kvalifikovaný vrcholový management, potřebná restrukturalizace proběhla (nebo je před dokončením). Je nutné souhlasit s Cardiffskou zprávou, že „výrazně lepších výsledků bylo dosahováno u podniků pod zahraniční kontrolou“. Pokud jde o národní hospodářství, hlavní restrukturalizační aktivity ještě nebyly plně dokončeny; jde především o reformu finančního trhu a bankovnictví, přizpůsobení legislativy a výkonu práva potřebám tržní ekonomiky, reformu vztahů mezi vlastníky, statutárními orgány, managementem a ostatními zájmovými skupinami (tzv. corporate governance), reformu státní správy, boj proti korupci atd. V této souvislosti někteří ekonomové poukazují na nedocenění úlohy státu a jeho funkcí v období transformace jako „naprosté nezbytnosti stabilizujícího systémového, institucionálního, legislativního, trestně postihového (penalizačního) atp. rámce fungování tržní ekonomiky jako předpokladu jejího úspěšného rozvoje“ (Chvojka, Zeman).

\section{Hlavní formy restrukturalizace společností}

Protože restrukturalizace ve světě i v našem hospodářství probíhají neustále, podívejme se na jejich hlavní formy, jak je uvádí současná odborná literatura ${ }^{16}$.

Z přehledu je vidět, že některé formy jsou v naší praxi málo rozššřené, nebo zcela neznámé. Formy restrukturalizace jsou členěny do několika skupin.

\section{Expanze}

Fúze a koupě (merger a acquisition)

Nabídka ke koupi (tender offers)

Joint ventures

\section{Výprodeje (sell-offs)}

Zřeknutí se firmy (spin-offs)

Prodej části firmy (divestitures)

III. Získání kontroly nad společností

Zpětný odkup (premium buy-back)

Dohoda o klidu (standstill agreement)

Opatření proti převzetí firmy (antitakerover amendment)

Boj o zastoupení (proxy contest)

\section{Změny ve vlastnické struktuře}

Výměna zdrojů (exchange offers)

Zpětný nákup akcií (share repurchases)

Privatizace (going private)

G. B. Steward, jeden z tvůrců nového ukazatele EVA (ekonomické přidané hodnoty), klasifikuje metody restrukturalizace společností do dvou skupin ${ }^{17}$ :

16 Brigham, E. F.: Fundamentals of Financial Management. Zhe Dryden Press, 1989. ISBN 0-03-025482-5. Copeland, T. E., Weston, I. F.: Financial Theory nad Corporate Polisy. Addison-Wesley Plublishing Company, 1988. ISBN 0-201-10648-5.

17 Steward, G. B.: The quest for value. The EVA ${ }^{\mathrm{TM}}$ Management Guide. HarperBusiness, 1991. ISBN 0-88730-418-4. 
- vertikální restrukturalizace (vertical restructurings), které mění strukturu aktiv a činností v rámci dosavadního podnikání (např. prodej a zpětný leasing, franchising, vertikální dezintegrace aj.),

- horizontální restrukturalizace (horizontal restructurings), která může zvýšit hodnotu firmy třemi způsoby: a) posílením jejího růstu pomocí akvizice, joint venture, nabídnutím akcií dceřiné společnosti veřejnosti,

b) oddělením podnikatelské jednotky (business unit) od firmy prodejem, spin-off, split-off nebo částečnou likvidací,

c) uskutečněním vnitřní „pákové“ (leveraged) rekapitalizace.

Podívejme se nyní na jednotlivé formy restrukturalizace podrobněji.

\section{Fúze}

V širším pojetí se za fúzi považuje jakýkoli transakce, která ze dvou nebo více jednotek vytvoří jednotku jednu. Jde tedy o splynutí jednotek (podniků, organizací). Rozlišuje se celá řada forem fúze. Dojde-li ke spojení firem pracujících ve stejném druhu podnikatelské činnosti, obvykle v rámci jednoho odvětví (napřs. spojení dvou oceláren, dvou leteckých společností), označuje se tato fúze jako horizontální; dojde-li ke spojení firem z různých fází zpracování (např. těžba nerostů a jejich zpracování), mezi nimiž je vztah dodavatel-odběratel, nazývá se vertikální. Oproti těmto formám (prováděným obvykle pro rozšîření počtu vyráběných a prodávaných výrobků nebo pro rozšiřrení teritoria) představuje tzv. konglomerátní fúze spojení vzájemně nezávislých firem z nesouvisejících oborů (z různých odvětví). Rozlišuje se i fúze přirozená a nepřirozená. Fúze přrirozená je taková, ve které větší společnost $\mathrm{s}$ hodnotnějšími akciemi pohltí menší společnost $\mathrm{s}$ méně hodnotnými akcemi. Fúze nepřirozená je taková, kdy menší společnost s hodnotnějšími akciemi přebírá větší společnost s méně hodnotnými akciemi. Existuje několik způsobů, jak ke spojení firem dochází. Uvádí se statutární fúze (statutory merger), která je spojením dvou nebo více firem, kdy jedna $\mathrm{z}$ nich přežije pod vlastním jménem, zatímco ostatní přestanou existovat jako samostatné právní jednotky, statutární konsolidace, splynutí (statutory consolidation), což je fúze, při které jako právní jednotky zaniknou všechny společnosti a vznikne nová společnost. Přes vznik velkého počtu různých způsobů restrukturalizace, zůstává fúze jejich hlavní formou. Důvodem pro fúze je obvykle snaha získat větší podíl na trhu a tím i konkurenční výhodu plynoucí z ekonomie rozsahu. Tím obvykle roste hodnota spojené firmy; tj. tzv. synergie, o které pojednáme dále. Fúzí však roste nebezpečí omezení hospodářské soutěže; tomu by měly bránit antimonopolní zásahy vlády (u nás Úřadu na ochranu hospodářské soutěže). Fúzemi se budeme dále zabývat podrobněji.

\section{Koupě (akvizice)}

má velmi blízko k fúzi, někdy se ani tyto dvě formy neodlišují. Koupě se obvykle týká malé jednotky, která je tímto aktem pohlcena obvykle velkou firmou a jako samostatná jednotka přestává existovat.

\section{Nabídka akcionářùm k odkoupení jejich akcií (tender offer)}

spočívá v tom, že jedna firma dá peněžní nabídku na odkoupení akcií akcionářům druhé firmy at už se souhlasem vedení firmy nebo bez něho. Tím získá tuto firmu pod svou kontrolu. 


\section{Joint venture}

se týká jen části činnosti společnosti a je uzavírána na omezenou dobu (na 10 až 15 let, ale i na méně let). Každý ze spojených partnerů dále funguje jako samostatná firma; joint venture pak reprezentuje nově vzniklý podnik, řízený spojeným managementem obou (nebo i více) mateřských firem.

\section{Odprodeje}

Dvěma hlavními formami odprodeje (sell-offs) jsou osamostatnění části podniku (spin-offs) a prodej části podniku (divestiture). První vytváří novou právní jednotku; její akcie jsou rozdělovány akcionářům mateřské společnosti v poměru k jejich původním podílům. Stejná skupina akcionářů pak vlastní stejný podíl akcií jako dříve, ale přes dvoje akcie. Pro akcionáře to není nijak důležitá změna, ale pro firmu, která ohlásí osamostatnění jednotky (vytvoření dceřiné společnosti) to obvykle znamená růst její hodnoty. Dochází však k oddělení rízení, čímž po čase nová jednotka může rozvíjet vlastní podnikatelskou politiku a strategii. Nová jednotka nedostává z původní společnosti žádné peníze.

\section{Divestitura}

zahrnuje prodej části firmy (části provozních aktiv) třetí straně, kterou obvykle je již existující firma, takže nevzniká nová právní jednotka. Někdy z části dříve existující firmy vznikne nová firmy a jsou vydány nové akcie veřejně nabízené. Původní firma tím získá peníze (cash), aniž by ztratila kontrolu nad novou firmou. Tato forma výprodeje se nazývá equity care-out. Rozdíly mezi formami výprodejủ (sell-offs) jsou arbitrární.

\section{Získání kontroly nad společností}

Odměna za zpětný odkup (premium buy-backs) představuje zpětný nákup podstatného podílu vlastnictví za cenu, která je vyšší než je tržní cena o prémii. Obvykle je sepsána dočasná dohoda (standstill agreement), kde „vykoupení“ akcionáři se zavazují, že se v budoucnu nepokusí znovu získat kontrolu nad společností. Dodatečná opatření ke ztížení získání společnosti pod kontrolu (antitakeover amendments) zvyšují procento potřebné k získání majority, např. na 80 \%; hovoří se o tzv. supermajoritě. Dalšími formami je odložení podmínek (staggered terms) pro ředitele, které odkládají po řadu let změny v kontrole, tzv. zlatý padák (golden parachutes), což jsou ustanovení v zaměstnavatelských smlouvách vrcholových řídících pracovníkủ, které upravují náhrady za ztrátu zaměstnání při změnách řízení společnosti. Zlatý padák je v poslední době uplatňován i u nás (napřr. v bankách).

\section{Změny ve vlastnické struktuře}

Čtvrtou skupinou forem restrukturalizace firem jsou změny ve vlastnické struktuře. Jde o přímou výměnu dluhu nebo prioritních akcií za společné akcie nebo obráceně (through exchange offers), nebo o zpětný nákup části dosud nesplacených akcií (share repurchase), kterým se mění podíl na kontrole firmy, nebo úplná koupě majetku dříve veřejné firmy malou skupinou vlastníků (going private transaction); tvoří-li tuto skupinu dosavadní management firmy, je tato koupě označována jako výkup firmy managementem, nebo stručně manažerský výkup (management buy-out - MBO), vstoupí-li tam i vnější investoři, kteří zajistí peněžní fondy, hovoří se o zadluženém výkupu („leveraged buy-outs - LBOs“). Přes vznik mnoha a mnoha nových forem restrukturalizace, hlavní formou stále zůstává fúze, kterou se nyní budeme zabývat podrobněji. 


\section{Fúze -převažující forma finanční restrukturalizace}

\subsection{Důvody fúze}

Proč je fúze hlavní formou restrukturalizace vysvětluje hned několik teorií, z nichž každá zdůrazňuje jiné důvody, které vedou firmy ke spojování.

Teorie účinnosti je nejrozšiřrenější; tvrdí, že je-li management firmy A výkonnější než management firmy B a získá-li firma A firmu B, pak účinnost firmy B je vyzdvižena na vyšší úroveň firmy A. Tím fúze zvýší celkovou účinnost nové firmy i celého národního hospodářství. Současně dochází ke zvýšení hodnoty firmy; zvýšení hodnoty se vysvětluje tzv. synergií. Synergie způsobuje, že výsledná hodnota spojené firmy je vyšší než součet hodnot obou fúzovaných firem:

$\mathrm{H}_{\mathrm{AB}}>\mathrm{H}_{\mathrm{A}}+\mathrm{H}_{\mathrm{B}}$.

Př́růstek hodnoty ze spojení je dán jejich rozdílem:

$\Delta \mathrm{H}=\mathrm{H}_{\mathrm{AB}}-\left(\mathrm{H}_{\mathrm{A}}+\mathrm{H}_{\mathrm{B}}\right)$.

Přesto, že kritici této teorie tvrdí, že hodnota je konstantní, tj.

$\mathrm{H}_{\mathrm{AB}}=\mathrm{H}_{\mathrm{A}}+\mathrm{H}_{\mathrm{B}}$

je teorie synergie přijímána jak teoretiky, tak i v praxi; důvodem je všeobecné uznávání růstu hospodárnosti (ekonomie) při růstu rozsahu výroby, tj. tzv. efekt koncentrace. Ten spočívá v tom, že

- fixní výrobní náklady jsou rozpouštěny do většího počtu výrobků,

- každá (i malá) firma potřebuje určitý počet pracovníků pro zajiššění řídících funkcí (výroba, výzkum, marketing, finance a další), kteří v menší firmě nejsou zcela využiti; při fúzi dochází $\mathrm{k}$ jejich plnějšímu využití a tím $\mathrm{k}$ vyšší hospodárnosti,

- fúze (především vertikální) přináší vyšší koordinaci řízení, nižší náklady na komunikaci mezi integrovanými stupni a nižší prodejní náklady.

Z praxe jsou však známy př́iklady, kdy je tomu naopak: fúzí vznikne složitá řídící struktura s větším počtem administrativních pracovníků; není pak daleko k tomu, aby začaly působit Parkinsonovy zákony. Nezanedbatelným problémem se jeví i rozdílnosti podnikových kultur, které mohou vyvolat a často vyvolávají pokles výkonnosti pracovníků.

Informační teorie vysvětluje důvody fúze tím, že většinou jsou akcie fúzované společnosti podceněny (např. proto, že management nepracuje na plný výkon - viz dř́ivější teorie nebo že společnost nabízející fúzi má mimořádné informace o budoucnosti aj.).

Teorie zastoupení vysvětluje fúzi tím, že manažeři obvykle vlastní jen malou část akcií firmy, kterou řídí a to je vede $\mathrm{k}$ méně intenzívní práci a větší spotřebě (služební auta, luxusní kanceláře), nebơ většinu nákladů nesou ostatní akcionáři. Jsou-li tyto náklady př́lišné, lze je fúzí redukovat - to je zájem akcionářù. Ale i manažeři mají zájem na fúzi - jejich postavení i platy závisí na velikosti firmy a fúze je jednou z forem jejího růstu.

Teorie volných peněžních prostředků vysvětluje důvody fúze z konfliktu mezi manažery a akcionáři v oblasti použití volných peněžních prostředků (volné peněžní prostředky - free cash flow - je přebytek hotovostí nad investičními potřebami). Podle této teorie volné peněžní prostředky vyplácené akcionářům snižují finanční zdroje, které jsou v rukou manažerů a tím snižují i jejich moc. Ti se proto obracejí na kapitálové trhy a potřeby firmy fi- 
nancují dluhem. Kromě toho užití volných peněžních prostředků pro fúzi nepřináší daňové zatížení firmy ani akcionářů (ukážeme dále).

Teorie tržní síly vychází z toho, že fúze zvyšuje podíl firmy na trhu a tím i její hodnotu. To ovšem vede $\mathrm{k}$ monopolním tendencím a $\mathrm{k}$ „nepatřičné koncentraci“ $\mathrm{v}$ průmyslu. Tomu obvykle brání zákony; např. v USA, když 4 nebo méně firem se podílí 40 nebo více procenty na prodeji (tržbách) daného trhu, pak „nežádoucí koncentrace“ existuje. V roce 1982 byla přijata směrnice pro fúze, která je založena na tzv. H-indexu (Herfindahl index), který zahrnuje trh akcií všech firem v průmyslu a je založen na ukazateli rozptylu; tím je př́snější než dříve citovaná směrnice vymezující koncentraci v procentech. Proti těmto zákonným omezením fúzí někteří ekonomové argumentují tím, že rostoucí koncentrace je výsledkem konkurence a ta mezi velkými firmami ještě vzrůstá.

Daňový efekt bývá častým podnětem pro fúzi, ale hlavní roli nehraje. V západních zemích a USA firmy mají především možnost přenášet provozní ztrátu do přístích let a tak snižovat daňový základ, dále substituovat kapitálové výnosy běžným ziskem, použít akumulované ztráty fúzované firmy ke snížení daňového základu původní firmy aj. Má-li např̀. vysoce zisková firma s velkými volnými prostředky nedostatek investičních př́ležitostí, použije je k nákupu jiné firmy, což oproti jejich jinému použití (např. zvýšení dividend) nemá žádný bezprostřední vliv na daně firmy ani akcionářů. Firmy musí ovšem pečlivě zvážit, zda fúze v těchto př́padech není v rozporu s daňovými a jinými zákony; ty tuto možnost v ČR dosud nepřipouštějí.

\subsection{Postup fúzování}

Ve většině případů $\mathrm{k}$ fúzování firem dochází tak, že větší ze dvou firem se rozhoduje (o důvodech jsme se již zmínili) koupit jinou firmu, jedná o její ceně a je-li cena přijatelná, firmu koupí. Iniciátorem fúze obvykle bývá firma hledající firmu, kterou chce koupit. Stává se však i to, že iniciátorem je firma, která chce být koupena (např. firma, která se dostala do finančních potíží). Firma, která chce jinou firmu získat, nazýváme nabývající společností (acquiring company), firmu, která má být koupena cílovou společností (target company). Najde-li nabývající společnost vhodnou firmu, musí stanovit vhodnou cenu nebo její rozpětí, kterou je ochotna zaplatit. Musí se rozhodnout, jak bude přistupovat k managementu cílené firmy. Má-li jistotu, že management koupi schválí, pak mu navrhne cenu a vhodné podmínky koupě. Je-li dosaženo dohody, pak obě skupiny manažerů vypracují projekt na fúzi pro valné hromady akcionářủ obou společností. Jestliže valné hromady fúzi schválí, potom nabývající firma od akcionářù cílové společnosti koupí jejich akcie, za které zaplatî budỉlastními akciemi (pak se akcionáři cílové společnosti stanou akcionáři nabývající společnosti), penězi nebo dluhopisy. Takováto transakce se označuje za přátelskou fúzi (friendly merger). Jestliže manažeři cílové společnosti fúzi odmítnou (např. pro nízkou navrženou cenu, nebo že si chtějí udržet zaměstnání), management nabývající společnosti se obrátí prímo na akcionáře cílené společnosti s nabídkou na odkoupení jejich akcií. To je obvykle tzv. nepřátelská fúze (hostile merger). Cena za akcie musí být stanovena tak, aby akcionáři své akcie prodali.

\subsection{Hodnocení fúze}

Nabývající společnost postupuje podle obvyklé procedury kapitálového rozpočtování : zjišluje, zda současná hodnota cash flow plynoucí z fúze bude vyšší než cena, která musí být zaplacena za cílovou společnost. Je-li cena vyšší, fúze se může uskutečnit. Jiné kritérium mají akcionáři cílené firmy: fúzi schválí, je-li nabízená cena za akcii vyšší než současná 
hodnota cash flow, kterou očekávají, že obdrží v budoucích letech, bude-li firma dále pracovat jako samostatná společnost. Nabývající firma obvykle postupuje v těchto krocích:

1. odhad cash flow, který plyne z fúze, 2 . stanovení ceny cílové společnosti, 3 . stanovení vlivu fúze na výnosnost vlastního kapitálu (ROE) 4. rozhodnutí v jaké formě bude koupě zaplacena (hotově, akciemi, cennými papíry). Prvními dvěma kroky se budeme podrobněji zabývat dále.

Z hlediska finančního hodnocení fúze je nutné rozlišit: 1. provozní fúzi, při které obě společnosti jsou integrovány a využivají tak synergického efektu, 2. finanční fúzi, ve které společnosti nebudou pracovat jako jedna integrovaná jednotka a tudíž žádné významné ekonomie nebude dosaženo.

\section{Odhad budoucího cash flow}

Snáze je budoucí cash flow zjistitelný při finanční fúzi. V čistě finanční fúzi je budoucí cash flow dán sumou očekávaných cash flow obou společností pracujících i po fúzi odděleně.

Při provozní fúzi je budoucí cash flow obtížněji zjistitelný. Protože obvykle hlavním důvodem fúze je efekt synergie, je nutné jej vhodně postihnout. Při tom se nesmí opomenout nově vzniklé náklady (např. dodatečná režie), které mohou kladný efekt fúze zcela strávit. Př́i zjištování cash flow (čistého zisku) se postupuje standardním postupem podle této tabulky:

Čisté tržby

- proměnné náklady

- fixní náklady kromě odpisů

- odpisy budov

- odpisy zařízení

- zisk před úroky a zdaněním /EBIT/

- úroky

- zisk před zdaněním /EBT/

- daně

Čistý zisk /EAT/

+ odpisy

cash flow

\section{Stanovení hodnoty cílové společnosti}

Postupuje se standardní procedurou oceňování firmy ${ }^{18}$. K tomu je nutné:

1. mít k dispozici řadu finančních výkazů (výsledovek včetně plánových), z nichž lze odvodit očekávané budoucí cash flow,

2. vypočítat diskontní sazbu (cenu kapitálu),

3. očekávaný cash flow se odvodí z této tabulky (navazuje na výše uvedenou tabulku):

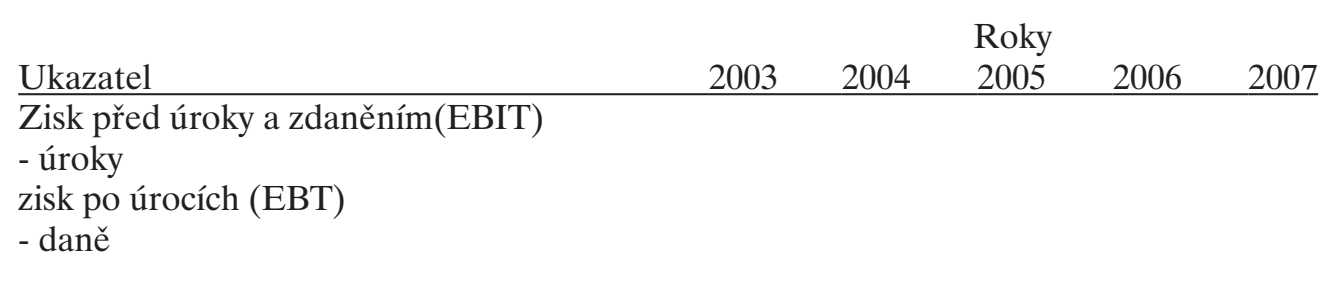

18 Kislingerová, E.: Oceňování podniku, Praha, C. H. Beck, 1999. 
zisk po zdanění (čistý zisk)

+ odpisy

cash flow

- částka na rozvoj (investice, změna pracovního kapitálu)

cash flow k dispozici (free cash flow)

+ cílová hodnota

čistý cash flow

Odhad se obvykle provádí pro období 5 let, pro další léta se počítá tzv. cílová hodnota (terminal value). Cílová hodnota se počítá jako perpetuita, bere se v úvahu předpokládaný růst cash flow v dalších letech, o nějž se snižuje použitá diskontní sazba (je-li např. diskontní sazba $20 \%$ a předpokládaný růst cash flow v budoucích letech $8 \%$, pak nová diskontní sazba pro výpočet cílové hodnoty je $20-8=12 \%$ ). Takto se diskontní sazba počítá při aplikaci modelu s konstantním růstem, který je v praxi převažující. Diskontní sazba se odvodí z bezrizikové sazby, rizikové prémie a beta koeficientu. Pomocí zjištěné diskontní sazby vypočteme současnou hodnotu budoucích cash flow. Vypočtenou současnou hodnotu budoucích cash flow porovnáme s cenou za cílený podnik. Platí: jeli současná hodnota budoucích cash flow vyšší než cena, za kterou nabývající firma cílenou firmu získá, pak je pro ni fúze akceptovatelná, a obráceně.

Výše uvedený postup hodnocení efektivnosti fúze je některými teoretiky kritizován a označován za nebezpečný. Vytýkají mu především to, že „i nejchytř̌ejší a nejzkušenější analytik může udělat při hodnocení podniku chybu“, především pak v odhadech budoucích cash flow. Navrhují proto tento postup:

1. za výhodnou fúzi považují takovou, při které zisk z fúze převýší náklady na fúzi. Zisk je rozdílem mezi hodnotou spojené firmy a oddělených jednotek:

$$
\mathrm{Z}=\mathrm{H}_{\mathrm{AB}}-\left(\mathrm{H}_{\mathrm{A}}+\mathrm{H}_{\mathrm{B}}\right)
$$

Ziskem obvykle je úspora nákladů vzniklá spojením firem.

2. Od zisku je tř̌eba odečíst náklady na fúzi, ty jsou dány rozdílem hotovostní platby $\mathrm{P}_{\mathrm{B}} \mathrm{a}$ hodnoty firmy B, tj. částky, kterou získali akcionáři firmy B:

Náklady fúze $\mathrm{N}=\mathrm{P}_{\mathrm{B}}-\mathrm{H}_{\mathrm{B}}$

3. Čistá současná hodnota fúze je rozdíl mezi ziskem a náklady:

$\check{\mathrm{CSH}}=\mathrm{Z}-\mathrm{N}$

Dosazením původních výrazů dostaneme:

$$
\check{\mathrm{CSH}}=\mathrm{H}_{\mathrm{B}}-\left(\mathrm{H}_{\mathrm{A}}+\mathrm{H}_{\mathrm{B}}\right)-\left(\mathrm{P}_{\mathrm{B}}-\mathrm{H}_{\mathrm{B}}\right)
$$

4. Platí, že fúze je pro firmu A výhodná, když čistá současná hodnota je kladná:

$$
\text { ČSH > O. }
$$

Je-li platba za cílovou firmu v akciích, potom náklady na fúzi závisí na ceně akcií po uskutečnění fúze. Bude-li fúze úspěšná, cena akcií vzroste a akcionáři koupené společnosti se potom budou podílet na zisku. Slabinou tohoto postupu je to, že se předpokládá existence tržních hodnot obou firem (dřive uvedený postup počítá cenu pomocí budoucích cash 
flow). V naší současné praxi bude zřejmě nutné používat oba způsoby hodnocení efektivnosti fúze $\mathrm{e}^{19}$.

\section{Zvláštnosti finanční restrukturalizace v ČR}

Formy restrukturalizačních programů v podmínkách vyspělých tržních ekonomik byly uvedeny v předchozí části. V České republice se v současné době nalézáme ve zcela specifické situaci. To souvisí s tím, že je $\mathrm{v}$ podstatě dokončena ekonomická transformace a $\mathrm{z}$ části i adaptace ekonomiky. Právě toto období, kdy skončila nebo končí druhá resp. třetí vlna privatizace, lze pozorovat řadu jevů, které svědčí mimo jiné o aktuální potřebě finanční restrukturalizace řady firem. Na základě poznatků dosavadního vývoje lze konstatovat, že restrukturalizační programy se výrazně liší podle toho, zda se jedná o velké, dříve státní podniky, nyní privatizované akciové společnosti, nebo po roce 1989 vzniklé soukromé firmy.

Těžiště problémů první velké skupiny firem, tj. velkých, původně státních podniků spočívá v tom, že se jedná o firmy, které z pohledu účetnictví jsou př̌kapitalizovány. Konkrétně to znamená, že mají př́liš velký rozsah vlastního kapitálu ve vztahu ke stálým aktivům. Tento jev je ovšem často vyvolán především historicky tím, že vlastní kapitál vznikl jako suma dř́ivějších fondů (fond základních prostředků, fond rozvoje aj.), z nichž bylo administrativní cestou vytvořeno základní jmění, odečetlo se $10 \%$ a vznikl rezervní fond. Takto v mnoha případech vzniklo základní jmění (dnes základní kapitál) a vlastní jmění (dnes vlastní kapitál) jako výchozí základ pro kupónovou privatizaci, a nejen pro ni. Tyto firmy se zpravidla již dnes potýkají s problémem nereálnosti takto uměle zkonstruovaného základního resp. vlastního kapitálu a hledají cesty a prostředky, jak nastálou situaci řešit. Proti takto vytvořenému vlastnímu kapitálu stojí majetek (aktiva), který rovněž bude muset $\mathrm{v}$ nejbližší době projít procesem restrukturalizace a přizpůsobení se novým podmínkám. Bývalé státní podniky jsou typické tím, že jsou relativně velmi dobře vybaveny co do staveb, budov, strojů a zařízení. Tyto majetkové části obsahovaly a u některých podniků dosud obsahují takové položky, jako rekreační objekty, obytné budovy, zdravotnická zařízení, které postupně byly nebo budou muset být vyloučeny ze souboru majetku využívaného pro podnikatelské účely. Některé firmy $\mathrm{k}$ tomuto kroku přistoupily již v rámci zpracování privatizačního projektu, ale některé, z důvodů nepochopitelné setrvačnosti a konzervativizmu, ponechaly tyto složky v souboru majetkových částí, i když je to stojí značné režijní výdaje. U řady podniků neodpovídá instalovaná výrobní kapacita v budovách, stavbách, strojích a zařízeních požadavkům trhu; nadbytečná výrobní kapacita vyvolává fixní náklady, které zdražují výrobky. Častou příčinou finančních potíží je proto samotná provozní činnost (nevhodný a př́iliš široký výrobní sortiment, zastaralé výrobky, nadbytečné zásoby, zastaralá technologie a výrobní postupy, špatná organizace výroby a práce, atd., atd.). Je na managementu, aby včas rozpoznal bližící se krizi a začal realizovat ozdravná, restrukturalizační opatření; v počátečních fázích potíží (pokles odbytu, růst zásob) to může stačit svými silami, později by si měl vyžádat analýzu od externí poradenské firmy. Opatření v oblasti provozní a finanční by měly jít ruku v ruce. Součástí analýz by měla být i analýza silných a slabých míst a ohrožujících jevů (analýza SWOT), mezipodnikové srovnání (především srovnání s hlavními konkurenty resp. lídry v oboru), analýza vývojových trendů aj. Tyto velké bývalé státní podniky jsou mimo jiné také jako dědictví minulosti ve značném rozsahu úvěrově zatížení, které je zpravidla koncentrováno do jednoho peněžního ústavu. Také v této souvislosti se stává aktuální některá z forem restrukturalizace pasiv.

19 Blíže k této problematice viz Mařík, M. a kol.: Metody oceňování podniku. Praha, Ekopress, 2003. ISBN 80-861119-57-2. 
Proti těmto firmám, které se jeví z účetního hlediska jako překapitalizované, stojí velká skupina podniků a firem, které vznikly bezprostředně po roce 1989 , kdy poprvé byl umožněn vznik soukromého sektoru v podnikatelské sféře. Ty se liší od první skupiny především tím, že je lze označit jako silně podkapitalizované. Vznik těchto firem se datuje do doby, kterou můžeme označit jako dobu absolutního nedostatku domácího kapitálu. Společnosti a podniky jednotlivce, které v té době vznikaly, nebo ještě vznikají, jsou charakteristické především tím, že mají rozsah základního kapitálu roven minimální povinné hranici plynoucí ze zákona, i když často povaha podnikatelské činnosti by vyžadovala vyšší kapitálové vybavení, především vyšší rozsah vlastního kapitálu. Tato skupina podkapitalizovaných podnikủ je př́iznačná zpravidla tím, že podniká v perspektivním oboru, má zajímavý výrobní program, avšak trvalý nedostatek finančních zdrojů, což se stává limitujícím činitelem rozvoje firmy. Právě tyto firmy budou mít postupně zájem, jestliže budou chtít expandovat, o fúzi s jinou, kapitálově silnější firmou, často i zahraniční. V podmínkách České republiky tedy existuje zcela specifická situace, $\mathrm{k}$ jejímuž řešení lze do určité míry využít dříve uvedené postupy, avšak jejich výběr a aplikace musí vycházet ze zvláštností jedné resp. druhé skupiny podniků, které postupně budou procházet procesem restrukturalizace. Podniky, které se jeví jako překapitalizované se dnes potýkají s nesprávně stanovenou velikostí základního kapitálu. Pro české subjekty platilo pravidlo, že základem je účetní hodnota; to bylo přímo v rozporu se základními přístupy k posuzování investičních příležitostí, kdy základem je budoucí výnos investora. Dnešní praxe soudních znalců a odhadců ukazuje, že reálná hodnota těchto podniků se pohybovala okolo $10 \%$ účetní hodnoty.

Zatím jsme pojednávali o restrukturalizaci a revitalizaci co by ekonomických kategorií. Podívejme se nyní na jejich pojetí z hlediska našeho práva.

\section{Restrukturalizace a revitalizace $\mathrm{z}$ hlediska českého práva}

Restrukturalizace a revitalizace jsou ekonomické kategorie, které naše právo nijak nevymezuje. Právo však (především Zákon o konkurzu a vyrovnání - ZKV, Obchodní zákoník a Trestní zákoník) vymezuje prostor, ve kterém mohou probíhat. Jak ukazuje J. Zelenka, ${ }^{20}$ jde především o úpadek, kde podle zákonné definice „dlužník je v úpadku, jestliže má více věritelů a není schopen po delší dobu plnit své splatné závazky" (úpadek ve formě insolvence), nebo kdy „osoba má více věřitelů a jestliže její splatné závazky jsou vyšší než její majetek" (úpadek ve formě předlužení). V obou případech, kdy nastal zákonem definovaný úpadek, může restrukturalizace a revitalizace probíhat pouze v mezích vymezených zákonem o konkurzu a vyrovnání. Pokud procesy restrukturalizace a revitalizace budou probíhat mimo rámec tohoto zákona, vystavují se statutární orgány dlužníka majetkovým osobním a podnikatelským sankcím a riziku trestního stíhání. Z hlediska práva při restrukturalizaci, spíše však při reorganizaci (viz Zelenka), jde o předmět, tj. dlužníkův podnik (věci, práva, majetkové hodnoty), při revitalizaci o osobu dlužníka samotného, kterou „budeme oživovat, obnovovat i jinak křísit“. Toto rozlišení je důležité v případě vyrovnání, které umožňuje dlužníkovi jeho další existenci jako ekonomickému subjektu, tj. jeho revitalizaci (o možnostech revitalizace dlužníka pojednává ZKV v paragrafech 1, 5, 34, 44, o možnostech restrukturalizace dlužníkova majetku v paragrafech 18 a 27). Názor J. Zelenky, že je nutné rozlišovat mezi restrukturalizací a revitalizací pokud se týká i jejich předmětu (restrukturalizace se týká podniku, revitalizace majitele), je podnětný a bude nutné jej dále rozpracovávat.

20 ZELENKA, J.: Soudní restrukturalizace a revitalizace, úpadek a možnosti jeho řešení dané právním rámcem - www.esipa.cz/dokumenty. 
Zajímavé je, že podobné problémy při revitalizaci a bankrotu podniku existují i v USA. Pî́se o tom R. C. Higgins ${ }^{21}$ : „Za posledních dvacet let došlo v konkurzním právu USA ke značnému posunu od ochrany práv věřitelů k péči o zachování pracovních míst zaměstnanců podniku, který se ocitl v nesnázích, zpravidla s cílem zkrachovaný podnik regenerovat. Protože toto je nyní hlavním cílem konkurzních řízení, zdá se být téměř nemožné spolehlivě předvídat, koho vlastně bankrot firmy doopravdy postihne. Především se při bankrotu dostanou pozůstatky společnosti do rukou konkurzního soudce a spousty advokátů, z nichž každý zastupuje nějakou poškozenou stranu ... A manažeři a vlastníci podle svého štěstí mohou vyjít s posílenou firmou nebo také s prázdnýma rukama ... V této chvíli je otevřenou otázkou, zda sílící kritické hlasy přimějí brzy Kongres k provedení důkladné generální opravy právního systému upravujícího bankrot v USA. Ovšem uvážíme-li, jak mnoho členů Kongresu jsou advokáty, a že právě právníci nejvíce profitují na stávajícím systému, pak je opravdu těžké hýřit zde optimismem“.

\section{Vstup ČR do EU - prověrka výsledků transformace a re- strukturalizace}

To, jak se Česká republika jako celek a jak se jednotlivé firmy připravily na vstup do EU, ukáže nejbližší budoucnost. Ponechme stranou „přizpůsobení se“, které měla na starosti vláda a podívejme se na podnikovou sféru. Zřejmě bez problémů přežijí období po vstupu do EU podniky s velkou účastí zahraničního kapitálu (kapitálu ze zemí s rozvinutým tržním hospodářstvím), které již delší dobu jsou napojeny na mateřské firmy, úspěšně své výrobky vyvážejí a staly se tak součástí evropské a globální ekonomiky. Obtîžnější situace nastane pro firmy, které se dosud nepřizpůsobily novým podmínkám; podle některých průzkumů, provedených ještě před vstupem, tři čtvrtiny podniků nevěnovaly přípravě na vstup patřičnou pozornost.

Obrovským rozšířením trhu a vytvořením jednotného evropského trhu vzniknou pro české podniky na jedné straně nebývalé možnosti rozšíření výroby a prodeje, na druhé straně vyroste jim nová konkurence tím, že na českém trhu se v daleko větší míŕe objeví výrobky z ostatních zemí EU, které mohou vytlačit české firmy z jejich dosavadního, jimi monopolizovaného trhu. České firmy proto musí hledat pro své výrobky volné místo na evropském, resp. světovém trhu, které mohou obsadit. Vstupem ČR do EU jim vzniklo i právo podnikat v celé EU; v tom je velká příležitost pro české podniky (musí se ovšem adaptovat na trh, kde chtějí podnikat).

Protože to jsou nakonec výrobky, které rozhodují o osudu firmy, musí české podniky počítat s tím, že jejich výrobky musí odpovídat nejen požadované technické a jakostní úrovni, které nabízejí konkurenční firmy, ale i bezpečnostním, zdravotním, hygienickým aj. předpisům. Ty jsou kontrolovány národními orgány dohledu nad trhem bez ohledu na to, kde výrobky byly vyrobeny. Podniky nesmí zapomínat na to, že výrobky jsou rozděleny do dvou oblastí (harmonizované a neharmonizované) a podle toho si zajistit ověření shody svých výrobků s technickými i ostatními požadavky.

Podniky se musí přizpůsobit i sociálnímu a pracovnímu zákonodárství, což se vcelku úspěšně děje. Dosud značné úkoly jsou před nimi v oblasti bezpečnosti práce a ochrany zdraví (požadavky na pracoviště, nástroje a nářadí, ochranné pomůcky, práce s karciogenními látkami atd.). Rovněž požadavky ekologické nejsou zdaleka plněny (ochrana vod a ovzduší, zacházení s odpady, obaly, nebezpečnými látkami, hlučnost aj.).

21 Vodáček, L.: Úkoly restrukturalizace českých podniků. Politická ekonomie 1998, č. 5. 
Shrneme-li to, co musí české podniky udělat, aby na novém trhu se svými výrobky obstály, je

- zvýšit produktivitu práce (ta je zhruba poloviční oproti SRN a dvoutřetinová celé $\mathrm{EU})$,

- zavést nové metody a způsoby řízení, především zavést hodnotový management (VBM Value Based Management), štíhlou výrobu (Lean Production) a systém JIT (Just in Time),

- vyrábět výrobky se zákazníky požadovanými technickými i jinými parametry,

- zvýšit kvalitu a snižit náklady výrobků,

- snažit se o to, aby se staly podniky světové tř́́dy (World Class Company).

Změny, kterými musí velká část našich podniků projít, vyžadují dodatečné náklady. Jde především o

- náklady související s převzetím velkého počtu směrnic o ochraně životního prostředí a jejich realizaci; tyto - většinou investiční náklady - budou tvořit největší část nákladů vynakládaných v budoucích letech;

- náklady související se zavedením směrnic o bezpečnosti práce a ochrany zdraví a jejich realizaci (rovněž většinou investičního charakteru),

- náklady na zlepšení pracovního prostředí, na prevenci chemických a jiných havárií,

- náklady na zavedení nových technologií (podle směrnic EU musí výrobci používat nejlepší z dostupných technologií),

- náklady na růst mezd (tím české podniky ztratí jednu z konkurenčních výhod) aj.

Na druhé straně české firmy mohou čerpat z některých fondů EU a zúčastnit se celé řady jejích programů.

\section{Shrnutí}

Česká ekonomika prošla za posledních patnáct let hlubokou transformací, která znamenala přeměnu centrálně řízené ekonomiky v ekonomiku tržní. Tato transformace zahrnovala systémové, institucionální a strukturální změny. Obsahem systémových změn byla privatizace, tj. přechod státem vlastněného majetku (podniků) do rukou soukromých vlastníků (v české ekonomice formou restitucí do rukou původních majitelů, transformací zemědělských družstev, malou privatizací a velkou privatizací; poslední formou prodejů zahraničním nabyvatelům a tzv. kupónovou privatizací). Liberalizace znamenala uvolnění většiny výrobních a spotřebitelských cen, zavedení vnitřní směnitelnosti koruny, zrušení monopolu zahraničního obchodu a liberalizaci pohybu zboží, peněz a kapitálu. České cestě transformace je vytýkána nedůslednost v zajištění transformace institucionálními změnami, především v oblasti práva.

Součástí transformace české ekonomiky byly změny její struktury, především věcné struktury (sektorové, odvětvové, oborové a výrobkové), velikostní struktury podniků a struktury zahraničního obchodu. Tyto změny obvykle označujeme jako restrukturalizaci (týká se národního hospodářství nebo podniků). Problémem byla a dosud je restrukturalizace bývalých velkých státních podniků. Protože především tyto podniky byly (a některé 
dosud jsou) spíše mrtvé, než živé, hovoříme o jejich revitalizaci. Ta je v podstatě prováděna přímo vládou nebo jí vytvořenými institucemi (Revitalizační agentura, Česká konsolidační agentura). Při rozhodování o revitalizaci podniku se bere do úvahy jeho budoucí hodnota a hodnota likvidační. Způsob výpočtu obou je uveden. Důležitou složkou restrukturalizace je restrukturalizace finanční, která má celou řadu forem, z nichž u nás nejznámější je fúze, akvizice a joint venture. Restrukturalizace našich podniků před vstupem ČR do EU byla a je jednou z podmínek úspěšného přežití na náročném evropském, resp. světovém trhu.

\section{Literatura}

1. ADAM, J. Co nás může naučit čínská strategie přechodu k tržní ekonomice. Politická ekonomie, 1997, č. 1 .

2. BRIGHAM, E. F. Fundamentals of Financial Management. The Dryden Press, 1989. ISBN 0-03-025482-5.

3. COPELAND, T. E. - WESTON, I. F. Financial Theory nad Corporate Policy. Addison-Wesley Publishing Company 1988. ISBN 0-201-10648-5.

4. GAJDOŠ, J. Obchodné retazce hypermarketov a maloobchodná się na východnom Slovensku in Ekonomika firiem 2003 (sborník z mezinárodní konference), Podnikovohospodárská fakulta Ekonomické university v Bratislave).

5. HEZCKO, J. Ekonomická reforma v širších souvislostech. Acta Oeconomika Pragensia, 1999, č. 3 .

6. HIGGINS, R. C. Analýza pro finanční management. Praha, Grada Publishing, 1997. ISBN 80-7169-404-5.

7. CHLUMSKÝ, J. Ekonomická konvergence mezi ČR a EU.Acta Oeconomica Pragensia 2002 , č.6.

8. CHVOJKA, P. - ZEMAN, K. Tendence dosavadního vývoje zemí střední a východní Evropy. Politická ekonomie, 2000 č. 6.

9. KADEŘÁBKOVÁ, A. Strukturální politika - trh nebo státní zásahy? Politická ekonomie, 1999, č. 3.

10. KISLINGEROVÁ, E. Oceñování podniku. Praha, C. H. Beck, 2001. ISBN 80-7179-529-1.

11. KLAUS, V.: Česká cesta. Praha, Profile s. r. o., 1994.

12. LAŠEK, J.: Strukturální aspekty transformace ekonomiky ČR. Politická ekonomie, 1998 č. 1

13. MAŘÍK, M. a kol.: Metody oceňování podniku. Praha, Ekopress, 2003. ISBN 80-861119-57-2.

14. MLČOCH, L.: Politická ekonomie, 1994,č. 3/1998

15. MYANT, M.: The Rise and Fall of Czech Capitalism. Development in the Czech Republic since 1989

16. STEWARD, G. B.: The quest for value. THE EVA Management Guide. HarperBusiness, 1991. ISBN0-88730-418-4. 
17. SYNEK, M.: Pět pravidel státní pomoci. Rozhovor v týdeníku Ekonom, 1999, č. 43.

18. TOŠOVSKÝ, J.: Ten years on (some lessons from the transition). Prague economic papers 2001, č. 1.

19. VEBER, J. a kol.: Management. Základy, prosperita, globalizace. Praha, Management Press, 2000. ISBN 80-7261-029-5.

20. VODÁČEK, L.: Úkoly restrukturalizace českých podniků. Politická ekonomie 1998, č. 5

21. ZELENKA, J.: Soudní restrukturalizace a revitalizace, úpadek a možnosti jeho řešení dané právním rámcem - www.esipa.cz/dokumenty. 